\title{
Ngendau: An Effort to Preservation Language in The Dayak Kenyah Tradition
}

\author{
Rika Istianingrum ${ }^{1}$, Sumiyadi ${ }^{2}$, Iskandarwassid ${ }^{3}$, Tedi Permadi ${ }^{4}$ \\ \{rika@uniba-bpn.ac.id ${ }^{1}$, sumiyadi@upi.edu², iskandarwassid@upi.edu ${ }^{3}$ tedipermadi@upi.edu ${ }^{4}$ \} \\ School of Postgraduates Studies ${ }^{1}$, Faculty of Language and Literature Education ${ }^{2,3,4}$ \\ Universitas Pendidikan Indonesia
}

\begin{abstract}
Oral tradition is not only a cultural treasure, but also has a role in the social practices of the owner's community. One such role is an effort to preserve language in the community traditions. Ngendau is the oral tradition of the Dayak Kenyah community. It is one of the tradition of singing poetry made by men and women, sometimes accompanied by musical instruments sampeq and dance. This study aims to describe the forms of Ngendau oral tradition as an effort to preserve language in Dayak Kenyah tradition. This research is descriptive qualitative and uses a sociolinguistic and ethnographic approach, collecting data in the form of observations, interviews, records, and notes. Data analysis uses interpretation techniques. This research is directed at the knowledge of the efforts made by the Dayak Kenyah community in preserving the Dayak Kenyah regional language through the oral tradition of Ngendau. The effort is in the form of performances in the customary traditions of the Dayak community. The results obtained are expected to support language preservation, language retention, and cultural wisdom of the archipelago.
\end{abstract}

Keywords: language preservation, oral tradition, Ngendau, Dayak Kenyah

\section{Introduction}

The global influence and multicultural society in East Kalimantan affect the awareness, attitudes and actions of some Dayak Kenyah people towards their language as one of cultural identities [1]. The Dayak Kenyah people tend to follow the import lifestyle as a result of the province of East Kalimantan being a center of tourism and an industrialization area which mostly uses Indonesian and foreign languages rather than using local languages. This is very apparent in the phenomenon of the lack of use of the Kenyah language in Dayak Kenyah community communication. The Dayak Kenyah community sometimes even uses mixed languages between the Kenyah language, Indonesian and foreign languages, rather than using the whole Dayak language.

The study of oral tradition has significance in linguistic studies, especially in field research in languages that do not have a written system and do not have written texts [2]. Many oral texts in any form express some of the culture and traditions of the speakers. Traditional stories, traditional songs, myths, group history, utterances in traditional and religious ceremonies. However, a number of writings indicate that the oral tradition of its existence is underestimated in the realm of the selection and use of language, meaning that the oral 
tradition is not included in the study of language shifts and language. In fact, the maintenance of oral traditions, local knowledge and language go hand in hand.

Language is the most significant vehicle for communicating and maintaining an intangible heritage and knowledge of local wisdom [2]. There is a close relationship between protecting or maintaining oral traditions and local languages. The reason, the loss of language means the loss of unique linguistic characteristics, the end result of which is to reduce, even eliminate oral tradition. That ended with the loss of local knowledge.

An efforts to preserve and maintain language must have integrated strategies and methods. As explained by Prompayuk [3]. in his research on the preservation of intangible inheritance in Thailand and developed countries which preserve intangible inheritance that contains tradition, the preservation process that enables preservation cannot favor the socio-economic structure of society. Similarly, as described by Ivankina [4] in her research on language preservation as a means of social evolution that language is a key position in culture, as a means of preserving the culture of ethnic groups.

Sociolinguistic and cultural studies are used to examine the relationship between language and society. The interaction between the community groups is good because the communication tools used are understood and understood by the language user community. Related to this explanation, Sumarsono [5] defines the sociolinguistics of a study of language that is associated with social conditions.

Liliweri [6] states that language has a considerable influence on how people think and see reality. The existence of language is not just a tool for communication, language also influences our thinking and culture. Language reflects the culture of society, culture influences the thinking and beliefs of the people of a nation because language reflects the focus of culture.

Oral tradition has an important value in the life of the community of its owner. In the oral tradition Ngendau contains values that are beneficial for the creation of an orderly, harmonious, peaceful, prosperous, and harmonious life. Oral tradition is the actualization of life values. That is, there is no oral tradition that is free from values that benefit the community of the owner.

Sibarani [7] that oral tradition is a traditional cultural activity of a community which is passed down from generation to generation with oral media from another generation of generations both in the form of arrangement of verbal words (verbal) and oral traditions that are not oral (non -verbal) Oral traditions are the community's traditionally cultural activities inheritied orally from one generation to the other generation, either the tradition is verbal or non-verbal.

The Dayak Kenyah community in the arts has beautiful oral literature. They like to sing expressions of heart and feelings. Chanting expressions of the stories of the life and heroism of his tribe is poured in poetry and music with rhythmic sentences. The chant is called Ngendau. Ngendau a tradition of singing poetry or poetry in a shout, together with young men and women [8].

Ngendau is usually carried out when there are at every traditional event such as, weddings, cultural festivals, Ngendau Arui (gathering together when relaxing and family), Pekenoq Tawai / Mubes (large deliberations), Ngendau Ajau in The U'o Ajau (harvest party) in the socio-cultural life of the Dayak Kenyah community. This was later made into an oral tradition by the Dayak Kenyah community. The oral tradition of Ngendau contains normative content, has a content of local values and wisdom that can function for social control and character building of the community. The Ngendau oral tradition is the identity and representation of the Dayak Kenyah community. Ngendau poems symbolize the life forms of the Dayak Kenyah 
community. A form of gratitude for nature and ancestors, gratitude for all God's creatures, a longing for something that is remembered, a sense of kinship with other siblings, and so on [9].

The problem in this paper is what are the forms of the Ngendau oral tradition in language preservation efforts carried out by the Dayak Kenyah community in maintaining language and tradition. The aim is to describe the forms of the Ngendau oral tradition as an effort to preserve language in the Dayak Kenyah tradition.

\section{Research Method}

This research is a field study and literature study. The type of research used is qualitative research. The approach used in this study refers to the ethnographic approach, Spradley [10] explains that the ethnographic approach seeks to pay attention to the meanings of the actions of events that occur in the tradition owner community. While the sociolinguistic approach seeks to bring the Dayak Kenyah community closer to its social and cultural life. Data collection techniques include: observation, interview, record, note. Data analysis techniques in this study using interpretive techniques that refer to data analysis techniques according to Endraswara [11] explain that in interdisciplinary techniques which means is to describe the folklore data relating it to the shape and elements of the nation's culture.

\section{Results And Discussion}

\subsection{Result}

The life of the Dayak Kenyah community is inseparable from nature, they develop along with nature both forests, rivers, animals, water and so on. The practices of their lives that are united with nature developed from a way, habits, into customs and culture which they then passed down from generation to generation. The meaning of nature is culturally reflected in various types of Dayak Kenyah culture in the form of dance, singing, carving, crafts, and traditions. The Dayak Kenyah community in the arts has beautiful oral literature. They like to sing expressions of heart and feelings. Chanting expressions of the stories of the life and heroism of his tribe is poured in poetry and music with rhythmic sentences. The chant is called Ngendau. Ngendau is used as a medium for expressing feelings in life stories, giving advice to young people or the public by using polite language. Even Ngendau oral traditions become a reference in carrying out some social activities as a civilized society.

However, along with the times, the Ngendau oral tradition has begun to be forgotten by the tradition owners and culture owners. Of course the Dayak Kenyah language began to be abandoned by the Dayak Kenyah community. Therefore, to maintain the continuity of the language, the Dayak Kenyah community even began to hold traditional events, such as the celebration of harvest, a large conference.

Preservation of language is the same as maintaining language. Preservation of language produced from a cultural product can be an effort to preserve the language. Language retention refers more to a situation where members of a language community try to protect their language by using it. Because language is always changing, what is expected is positive and stable change. That is, the language is still used by the speaker community and passed on to the next generation on an ongoing basis. 
Perez [12] explained in his research on indigenous languages, identities, and the legal framework in Latin America that people must increase respect for the plurality of cultures and languages that begin to assimilate. With so a sense to maintain the local language is very important for the community who owns the language.

This is the concept of language preservation in the oral tradition which can ultimately be used as an effort to maintain the language. In this sense, language survives dynamically despite changes and changes from generation to generation. Therefore, the importance of language preservation efforts in ethnic groups in Indonesia through oral traditions. As stated by Purnamawati [13] in her research related to the effort to conserve the tradition of the Perang Pandan in Bali that the efforts of preservation and conservation of oral traditions are through education and training.

Therefore, efforts to preserve the Dayak Kenyah language in this section are understood as ways, actions, or attitudes that can support the use of the Dayak Kenyah language and its survival from the effects of various social changes in social life through the Ngendau oral tradition which is still maintained by the Dayak Kenyah community in every event their traditional traditions.

\subsection{Discussion}

\subsubsection{Harvest Party (U’O Ajau)}

The Dayak Kenyah community has customary beliefs in carrying out agricultural ceremonies. The agricultural ceremony is called a thanksgiving harvest or harvest party. Throughout the year they celebrate the cycle of agriculture or life. Then when all their harvests go into the granary, the local community holds a harvest feast to offer to God.

One form of holding a harvest party or thanksgiving for the harvest in the Dayak Kenyah community is called $U^{\prime} O$ Ajau located in Rindang Benua Village, East Kalimantan.

The $U^{\prime} O$ Ajau tradition in the Dayak Kenyah community is carried out as an expression of gratitude that has been bestowed by the Universe to the farmers of Rindang Benua Hamlet and also as a medium of reinforcement against evil spirits, as a binder of solidarity and togetherness in society, as a means of asking for strength, protection and success of farming business, and of course as a means of public entertainment. The tradition of U'O Ajau in the Dayak Kenyah community is to signify the main meaning of gratitude to God Almighty, the Universe of Nature for health gains, safety at work, and success in harvesting crops.

The U'O Ajau traditional thanksgiving event was enlivened by a variety of Dayak Kenyah dances, including a welcoming dance, Ainan Letoq dance, Tebengang Madang dance, Ajay dance, corded dance, Udoq Aban dance, and closed with Mecaaq Udat tradition namely rice pounding dance or residents' yields. A dance of honor to the Universe through the media of rice which has been made into rice and put into mortars to pound with pestle into flour.

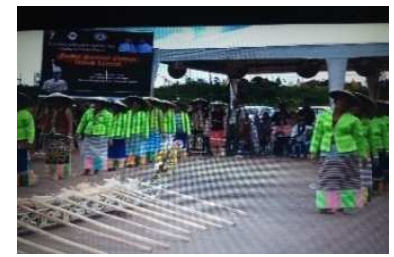

Figure. 1. Start of Ngendau

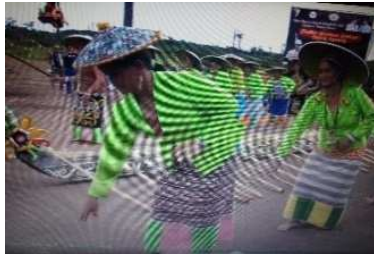

Figure. 2. Dance stages of planting rice

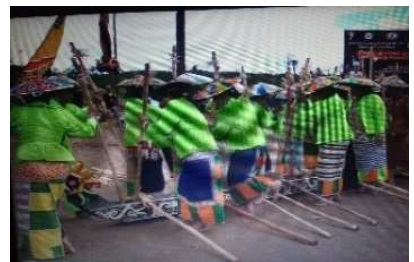

Figure. 3. Mecaaq Udat 
In the program One of the dance performances that demonstrate the agricultural stages of the Dayak Kenyah community which was closed with the ritual of Mecaaq Udat. In the dance begins with melodic poetry called Ngendau. They do Ngendau simultaneously led by a Julog. Julog or the controller is a leader who chants Ngendau poetry, which is followed by other controllers. Next is the lyrics of Ngendau in the Mecaaq Udat dance in harvest party.

The Kenyah Language
Ini kenei miq ini amai
Nei nggin tawai
Nei nggin tawai
Dalam dalam inan
Ateq lan aleq ina amai
Banggen banggen ne ilu amai
Kendaq tapen
Kendaq tapen
Kule kule layan
Ateq lan aleq ina amai

\author{
The English Language \\ here we come, sir \\ want to meet \\ want to meet \\ with all the heart \\ yes so, sir \\ we are busy, sir \\ in the hall \\ in the hall \\ get along well together \\ yes so, sir
}

The poem in above tells some people that Ngendau came to bring good news to the people (symbolized by the name of the father) to be together and gather to give thanks for the harvest of their fields. Ngendau poetry is more interpreted in the form of togetherness and harmony among Dayak Kenyah people. There are two things to be conveyed to the community, namely, thanksgiving to the ancestors, God for all the delegation of their crops and a sense of togetherness and harmony of the Dayak Kenyah community in conducting the event. Thanksgiving or harvest party. These Ngendau verses include Kendau Ajau. Meaning Kendau is delivered when it is related to the agricultural or field harvest event.

\title{
3.2.2 The Great Deliberations or MUBES (Pekenoq Tawai)
}

The indigenous Dayak Kenyah community has a tradition of great deliberation (Mubes) or what is called the Pekenoq Tawai. A tradition that is believed by the Dayak Kenyah community can be used as a medium for togetherness and meeting one another with extended families of Dayak Kenyah people who have spread across several regions in East Kalimantan and those in Sarawak (Malaysia).

The Pekenoq Tawai is held once a year, every three years, or every five years, it all depends on the agreement of the Dayak Kenyah community each sub-clan (lapoq or uma'), considering the Dayak Kenyah tribe itself has 22 sub-clans (lapoq). Of course the implementation of the Pekenoq Tawai was also based on the Dayak Kenyah community policy of each sub-clan (lapoq). As explained by Billa [14] that Dayak Kenyah is divided into 22 sub-tribes, which have their own names and each has a customary head, each sub-tribe is usually called lepoq / umaq which means village.

In one clan there are several sub-clans, of course this affects the language used by each sub-clan. Basically the language they speak is the same as the Kenyah language, but what distinguishes it is the dialect of letters when pronunciation in each sub-clan. Plurality between sub-clans has always occurred when they started making their own sub-clans. Even though there is a difference of one or two letters in the pronunciation or dialect of language, when there is interaction and communication in different clan societies, they still understand each other. Their strategy was to hold a Ngendau oral tradition in every traditional event, especially a large deliberation event (Pekenoq Tawai). 
This is similar to Sunarti's research [15] on the Lego-Lego oral tradition as an effort to cultivate and nurture Plurality and Multiculture in the Alor Tradition explaining that pluralism among Alor people has existed for a long time. Although progress has the potential for conflict among communities, they have several strategies to avoid it. This strategy is recognized as local wisdom. The ancestors taught them how to cultivate and maintain the plurality that exists in several concepts such as regional alliances and religious alliances. The media for learning plurality is through Lego-Lego dance performances that are transmitted orally. In the great deliberation (Pekenoq Tawai) activities there are various kinds of activities that are modern and past that are contested / contested between villages that are still one subclan. One of the contests in the Pekenoq Tawai activity was the Ngendau competition. Ngendau must be present and contested with the aim of preserving the culture of the Dayak Kenyah traditional arts. Next is one of the Ngendau poems performed at the Pekenoq Tawai in Mekar Baru Village.
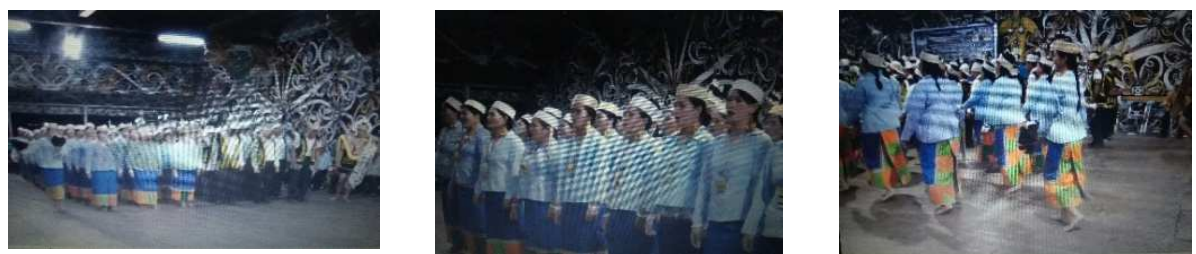

Pic. 4, 5, 6 Performance Ngendau from Mahak Baru Villallage

The Kenyah Laguage

Ini kenei miq telu amei

Nei nggin bangen nei nggin bangen tawei bangen tawei dalem inan

Atek telan le ina badi amei

Mbi miq muuot tuyen saten kenei miq nuyen

Nei nuyen ladung, nuyen ladung mubes

Bakung

Atek telan le ina badi amei

Jaat aleq gak janan amei

kadoq diaq, kadoq diaq mabuk uto mabuk uto ngalang janan

Atek telan le ina badi amei

Pempau Tuhan telu amei ilu sendeng, ilu sendeng nei petegoq nei petegoq usa iyung inan

Atek te lan le ina badi amei
The English Language

here we come, sir

bring happy / happy

come bring happy heart, happy heart in the soul it's true, sir

can not be imagined our painstakingly come, come sit together (meeting)

came to sit together (meeting) a large deliberation sub Bakung

indeed it is, sir

how ugly the streets are, sir

many are, many are carsick, carsick along the road

indeed it is, sir

praise/exalt our Lord, sir

we can, we can meet, can meet each other/ personally freelance

indeed it is, sir

The poem in above tells a number of people who Ngendau in the Pekenoq Tawai program, in Ngendau they tell their story when traveling from their village, namely Mahak Baru (East Kutai, East Kalimantan which borders Sarawak Malaysia). The story of the journey from the village to the village of Mekar Baru where the Pekenoq Tawai was held, according to the 
Dayak Kenyah community, Mahak Baru village, is a long journey that takes two days using landline vehicles with poor roads. Their travel story is retold in the form of rhythm, song and poem in Kendau which is then included in the Ngendau race.

\section{Conclusion}

An efforts to protect local languages cannot rule out oral traditions that exist in the local language community. One of the efforts made to preserve endangered languages is by research that is equipped with language documentation. The oral tradition of Ngendau is one of the efforts that must be made by the Dayak Kenyah community to preserve their local language. Through a number of performances or traditional and cultural events, the Kenyah regional language can be preserved and maintained properly. This of course can indirectly increase the vocabulary of the archipelago and also support Indonesian vocabulary.

\section{References}

[1] R. Istianingrum, "Eksistensi Bahasa Dayak Kenyah Di Kota Balikpapan Kalimantan Timur," Paramasastra, vol. 2, no. 1, pp. 160-176, 2015.

[2] Katubi, "Tradisi lisan dalam pergeseran dan pemertahanan bahasa kui di alor, nusa tenggara timur," Masy. Indones., vol. 37, no. 1, pp. 115-137, 2011.

[3] S. Prompayuk and P. Chairattananon, "Preservation of Cultural Heritage Community: Cases of Thailand and Developed Countries," Procedia - Soc. Behav. Sci., vol. 234, pp. 239-243, 2016.

[4] L. Ivankina and E. Anikina, "Language Preservation as a Means of Society Evolution," Procedia - Soc. Behav. Sci., vol. 206, no. November, pp. 354-358, 2015.

[5] Sumarsono, Sosiolinguistik. Yogyakarta: Pustaka Pelajar, 2011.

[6] A. Liliweri, Pengantar Studi Kebudayaan. Bandung: Nusa Indah, 2014.

[7] R. Sibarani, Kearifan Lokal: Hakikat, Peran, dan Metode Tradisi Lisan. Jakarta: ATL, 2012.

[8] E. Sedyawati, Konsep Tata Ruang Suku Bangsa Dayak Kenyah di kalimantan Timur. Jakarta: Departemen Pendidikan dan Kebudayaan RI, 1995.

[9] R. Istianingrum, "Ngendau Sebagai Representasi Masyarakat Dayak Kenyah: Proses Menuju Industri Kreatif," in Pendidikan Karakter dan Industri Kreatif dalam Perspektif seni Budaya di Era industri 4.0, 2018, pp. 548-556.

[10] J. Spradley, Metode Etnografi, vol. 66. Yogyakarta: Tiara Wacana, 2017.

[11] S. Endraswara, Metodologi Penelitian Folklor: Konsep, Teori, dan Aplikasi. Yogyakarta: Media Pressindo, 2009.

[12] I. C. Pérez, "Indigenous Languages, Identity a nd Legal Framework in Latin America: An Ecolinguistic Approach1," Procedia - Soc. Behav. Sci., vol. 212, pp. 111-116, 2015.

[13] I. G. A. Purnamawati, N. K. S. Adnyani, and I. N. Suastika, "The Conservation of Perang Pandan Tradition for the Socio- Economic Life of Adat Community in Tenganan Pagringsingan Bali," Procedia - Soc. Behav. Sci., vol. 211, pp. 135-141, 2015.

[14] M. Billa, Alam Lestari \& Kearifan Budaya Dayak Kenyah. Jakarta: Pustaka Sinar Harapan, 2006.

[15] S. Sunarti, A. Atisah, S. Suryami, and W. Firdaus, "Lego-Lego: An Attempt to Cultivate and Nurture Plurality and Multiculture in the Alor Tradition," in 1st Workshop on Environmental Science, Society, and Technology, WESTECH 2018, 2019. 